(sic, ha) de Cunplir (sic)». Lo cual, dentro de la terminología y lenguaje contractuales de la época, está apuntando claramente al tracista responsable de la obra en cuestión, como ya suponíamos e indicábamos, Jorge Manuel Theotocópuli; lo que ahora podemos comprobar y constatar sin duda alguna.

Diego SuÁREZ QUEVEDo

Universidad Complutense

\title{
PEDRO DE MAYORGA: ¿EL MAESTRO DE PALANQUINOS?
}

El Museo de la Iglesia de Oviedo posee desde su fundación en 1990 una pintura de finales del siglo XV que representa la Asunción de Nuestra Señora en presencia de un donante (óleo y temple/tabla, 87 x $88 \mathrm{~cm}$., cat. P 1, núm. inv. 213). Se trata de un depósito de la catedral ovetense que cuenta ya con algunas reseñas bibliográficas en el ámbito regional ${ }^{1}$. El soporte lo integran cinco tableros de pino encolados a arista viva, muy deteriorados por la carcoma, lo que interesó también a la pintura: casi una cuarta parte de su superficie se halla perdida. El aparejado es de yeso, con las juntas encañamadas. Fue restaurada en 1993 con motivo de la exposición Orígenes, donde figuró como anónima con la entrada número $289^{2}$.

En realidad, la obra procede del antiguo templo parroquial de Santa María del Naranco (Oviedo), establecido en el palacio altomedieval de Ramiro I (mediados del siglo IX). En ese emplazamiento la había descrito Miguel Vigil:

«Hay en la sacristía un cuadro pintado al óleo de 80 centímetros por lado con fondo dorado y buen dibujo: representa la Purísima Concepción adorada por cuatro ángeles vestidos y alados, viéndose el retrato del donante en actitud de orar, en la parte baja: pertenecía a fines del siglo XV o principios del siguiente, y conserva el marco original» $^{3}$.

Con toda probabilidad, la tabla provendría de aquel «retablo de costosas pinturas» que en 1856 menciona Francisco Javier Parcerisa, y que — sigue diciendo— fue reemplazado por el «pobre cura párroco [...] por otro de malísima talla» ${ }^{4}$.

La pintura fue depositada en la catedral por el cura ecónomo del Naranco el 23 de noviembre de 1931, firmando el recibo don Arturo Sandoval y Abellán, secretario capitular ${ }^{5}$. Desde esa fecha hasta su traslado al Museo, la tabla estuvo almacenada en las dependencias

1 Barón, Javier y González Santos, Javier, «Catálogo de las pinturas de la catedral de Oviedo», Liño, 7, Oviedo, Universidad de Oviedo, 1987, cat. 38, pp. 79-81. ÍD. e ÍD., «Corrigenda al catálogo de pinturas de la catedral de Oviedo», Liño, 9, Oviedo, 1990, cat. 38, p. 152. González Santos, Javier y Barón, Javier, La catedral de Oviedo y el Museo de la Iglesia, Oviedo, Fundación Municipal de Cultura del Ayuntamiento de Oviedo, 1995, p. 70. Platero Fernández-Candaosa, Ramón y Hevia Ballina, Agustín, «Museo de la Iglesia», en Guía de los Museos de Asturias, fascículo núm. 5, Oviedo, diario La Voz de Asturias, [1995], pp. 6 (reproducción) y 7 (texto). González Santos, Javier, ápud AA.VV., Catálogo del Museo de la Iglesia de Oviedo, cat. P 1 (en prensa) e ÍD., La catedral de Oviedo. Sancta Ovetensis, León, Edilesa, 1998, p. 103.

2 Paniagua Félix, Pedro, ápud Orígenes. Arte y cultura en Asturias. Siglos VII-XV, catálogo de la exposición celebrada en la catedral de Oviedo durante los meses de agosto-noviembre de 1993, Oviedo, 1993, pp. 461c462; sólo se reproduce un detalle: el busto de la Virgen y parte de un ángel del lado izquierdo de la tabla.

3 Miguel Vigil, Ciriaco, Asturias monumental, epigráfica y diplomática. Datos para la historia de la Provincia, vol. I, Oviedo, 1887, p. 218.

${ }^{4}$ Ápud Quadrado, José María, Recuerdos y bellezas de España. Asturias y León, Madrid, 1855, p. 247.

5 Archivo de la Catedral de Oviedo (A.C.O.): Papeles varios y curiosos, caja núm. 2, documento s/numerar. 


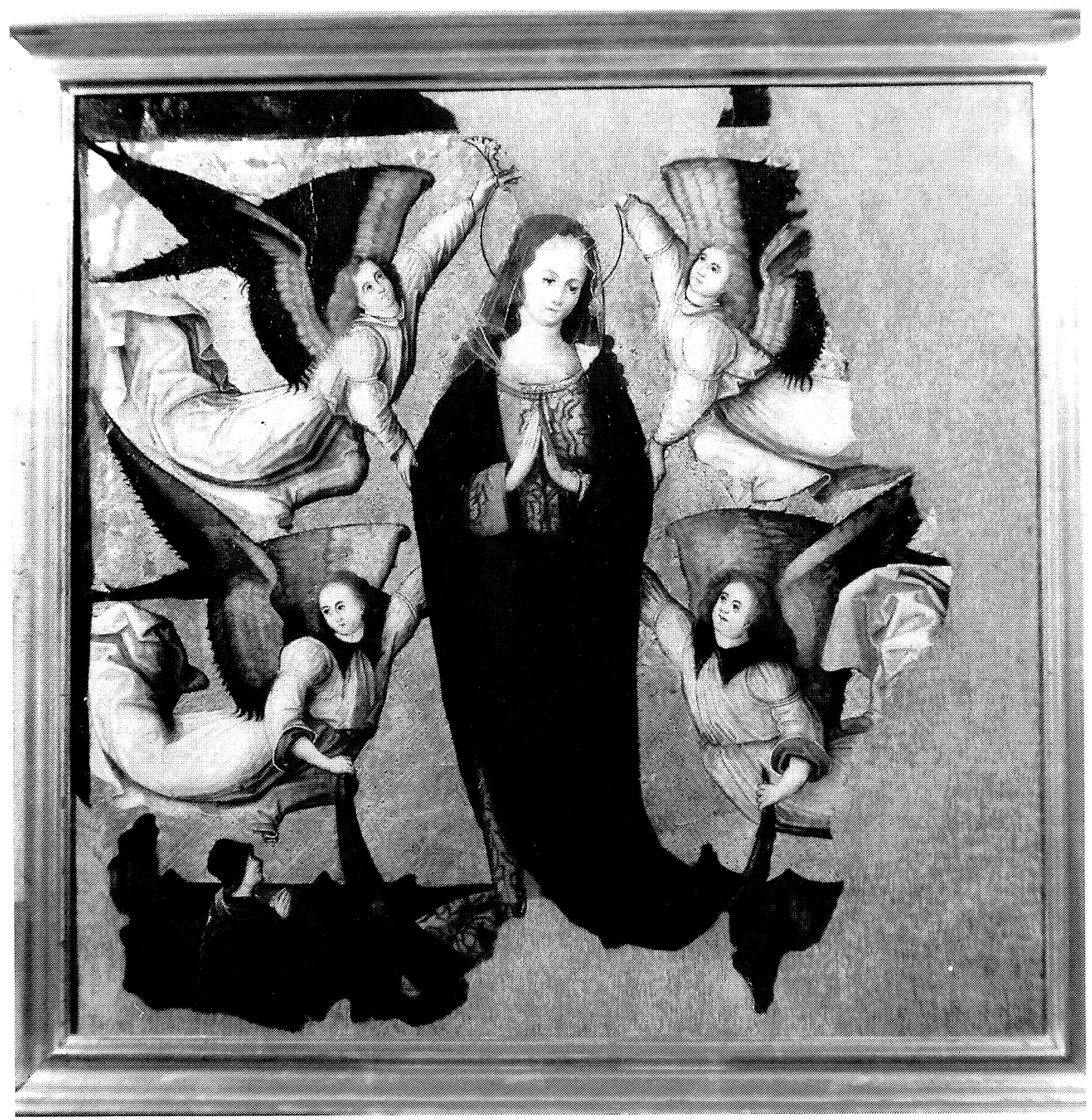

Figura 1. Maestro de Palanquinos ¿Pedro de Mayorga?, Asunción de Nuestra Señora con donante, c. 1487, temple y óleo/tabla, 87 x $88 \mathrm{~cm}$. Oviedo, Museo de la Iglesia de Oviedo (Foto Alonso). 
del claustro alto catedralicio, en un estado de semiabandono que favorecería su deterioro. Identificada en 1985, la dimos a conocer en 1987, siendo vuelta a exhibir en 1993.

Figura la visión de la Reina de los Cielos (la corona sólo se adivina en la parte izquierda, sobre la cabeza) manifestándose a un devoto en el misterio de su asunción y coronación; no parece que existiera otra figura en correspondencia simétrica con la de la izquierda ya que Miguel Vigil, que conoció el cuadro completo (hasta con su marco original), habla sólo de un donante. Sin embargo, la actitud humilde del semblante de Nuestra Señora (ojos entornados hacia la tierra con un velo de gasa cubriendo su cabeza) y las manos recatadamente juntas en gesto de oración, por un lado, y la presencia del creciente lunar sobre el que se yergue su grácil y sinuosa figura, la túnica de brocado rojo y oro bajo el manto azul (el color está muy oxidado), por otro, también aportan detalles de significación concepcionista. Este culto, popular en España desde mediados del siglo XV, fue refrendado por el papa Sixto IV en 1477 instituyendo la festividad de la Inmaculada Concepción ${ }^{6}$. Pese a ello, durante varias décadas, las primeras representaciones de este nuevo misterio se siguieron asociando, indiferenciadamente a las de la Asunción y Coronación de Nuestra Señora.

Por otro lado, el donante es un eclesiástico, un canónigo, como lo manifiesta su característico atuendo: balandrán con sobrepelliz y un bonete por tocado.

Resulta extraño, al menos en Asturias, explicar por qué una pintura de semejante calidad y antigüedad se hallaba en una parroquia rural como Santa María del Naranco. Los testimonios de pinturas tardomedievales sobre tabla en estas latitudes son tan escasos e irrelevantes como las noticias documentales, lo que permite concluir que este género no tuvo ningún arraigo en el mercado artístico regional del siglo XV. Esta situación, con excepciones bien conocidas y documentadas, se mantuvo hasta el siglo XVIII, momento en que se llega a constatar un relativo acomodado del género pictórico mobiliar en Asturias ${ }^{7}$. Sin embargo, el hecho de que el donante sea un canónigo podría darnos la clave de su verdadera naturaleza.

En efecto, acaso esta pintura sea el único fragmento del primer retablo mayor que tuvo la basílica ovetense y que, a partir de 1512, fue sustituido por el actual. Al parecer, fue don Diego Ramírez de Guzmán (obispo de Oviedo desde 1412 hasta † 1441) quien costeó la construcción de aquel retablo que presidiría, con suntuosidad pareja a la del recinto arquitectónico, el recién estrenado ábside catedralicio ${ }^{8}$. Consta además que por orden del cabildo fue renovado

6 Réau, Louis, Iconografía del arte cristiano. Iconografía de la Biblia. Nuevo Testamento, Barcelona, Eds. del Serbal, 1996 (1. ed., París, 1957), t. I, vol. 2, pp. 81-90 y 638-648.

7 A este fenómeno hemos hecho referencia en otros lugares: «Pervivencias medievales en las artes figurativas del siglo XVI: el Maestro de Celón y las manifestaciones pictóricas murales en la zona suroccidental asturiana», Liño, 10, Oviedo, 1991, pp. 93-111, y Los comienzos de la escultura naturalista en Asturias (1575-1625), Oviedo, Consejería de Cultura del Principado de Asturias, 1997, pp. 13-44, pássim.

${ }^{8}$ La noticia parte de Marañón de Espinosa, Alfonso (presb.), Historia eclesiástica de Asturias (c. 1614), Gijón, Monumenta Histórica Asturiensia, Gijón, 1977, p. 137 («Hizo sacar dos capillas a la diestra de la capilla mayor, donde ahora está la sacristía; hizo órgano y reloj, dio principio al retablo y al cuarto ángulo de la claustra; hizo la entrada antigua de la Iglesia y trabajó para traer la indulgencia perpetua que ahora tiene la Cámara Santa.»). Alfonso de Carvallo, Luis (S. I.), Antigvedades y cosas memorables del Principado de Astvrias [c. 1613], Madrid, Julián de Paredes, 1695, p. 440b. González Dávila, Gil, Teatro eclesiástico de la Sta. Iglesia de Oviedo. Vidas de svs Obispos, y cosas memorables de sv Obispado, Madrid, Francisco Martínez, M.DC.XXXV, pp. 46v-47r («Edificó dos Capillas à los lados de la Mayor; hizo el retablo della, órganos, y relox. Enlosó todo el claustro, y edificó el quarto ángulo»). Risco, Fray Manuel (O.S.A.), España Sagrada. Asturias, t. XXXIX, Madrid, 1795, p. $50 a$ («Comenzó el retablo mayor de su Iglesia que se tiene por uno de los mejores de España que șe hicieron en aquel tiempo»). De igual manera, en Jovellanos, Gaspar Melchor de, «La catedral de Oviedo», IV de las Cartas del Viaje de Asturias [1782], ed., prólogo y notas de José Miguel Caso González, Salinas, Ayalga Eds., 1981, t. I, § 41, p. 136; Ceán Bermúdez, Juan Agustín, «Adiciones» a las Noticias de los arquitectos y arquitectura de España desde su Restauración, por Eugenio Llaguno y Amírola, Madrid, 1829, t. I, p. 73, y Quadrado, 
en 1470-1471: en agosto de 1470, se dieron «2.000 maravedises al maestro de las imágenes» $\mathrm{y}$, el 18 de marzo de 1471, otros «3.300 maravedises de moneda nueva de los que había de haber al maestro de las imágenes, porque el chantre se los había emprestado a dicho maestro» ${ }^{9}$. Y, de nuevo, en 1487, en esta oportunidad cometiéndose la tarea a «Pedro de Mayorga, pintor, vesino de la cibdad de León», quien

«avía pintado e fecho çierta pintura en la dicha iglesia, espeçialmente en el altar mayor, por lo qual le avían de dar segund fuesen convenidos, veynte mill maravedises; que agora por quanto ella avía fecho mucho bien e tal que demandava en alguna manera mayor paga e satisfaçión, lo qual ellos acatando e mirando el grand trabajo que avía resçebido segund el tiempo e prisa en que lo sobredicho avía fecho, [...] e más le diesen goçosos, por rasón de lo que fas, mill maravedises» ${ }^{10}$.

El crecido importe liquidado por la catedral nos advierte del relieve e importancia de la obra emprendida en aquel retablo pero no aclara si los trabajos fueron de dorado, de pincel o de ambas cosas a un tiempo ${ }^{11}$. De la lectura de este asiento, lo que parece fuera de duda es que Pedro de Mayorga había sido el único responsable del trabajo como tal maestro, y que en ningún caso se trataba del partícipe de una mancomunidad de pintores o de un mero oficial.

La actuación de Mayorga en la catedral ovetense se verificó durante el pontificado de don Juan Arias de Villar (entre 1487 y 1498; muerto en Segovia en 1501). Fue Arias un emprendedor y cultivado obispo al que la catedral debe el cierre de las naves de su templo (1498) y la construcción de la sillería coral (1491-1497); también ordenó labrar para sí (aunque nunca llegaría a ocuparlo) un sepulcro en el muro septentrional de la capilla mayor (1498-1499), con estatua orante cuya atención iba dirigida hacia aquel retablo. No consta que la ampliación de éste se hiciera a instancias suyas, pero la presencia de Mayorga en Oviedo coincide con los primeros meses de gobierno de Arias de Villar que, como recuerda Risco, tomó posesión de la sede el 25 de agosto de $1487^{12}$. Es más: en el citado recibo del 26 de noviembre se declara que el pintor leonés había realizado un buen trabajo «segund el tiempo e prisa en que lo sobredicho [la pintura del retablo] avía fecho»; ello podría dar pie a pensar que el nuevo prelado hubiese urgido la conclusión del retablo tras su llegada a Oviedo.

Como quedó dicho, en 1512, veinticinco años después, este retablo, que integraba bultos y pinturas y cuyas dimensiones debieron ser bastante modestas (en todo caso, no parece que llegasen a la monumentalidad del actual y como mucho ocuparía sólo los paños centrales del

Asturias y León, p. 124. También Cuesta Fernández, José (presb.), Guía de la catedral de Oviedo, Oviedo, Diputación Provincial de Asturias, 1957, pp. 72 y 75-76 (hay reed.: Oviedo, 1995, pp. 50 y 54-55). Resume todas estas noticias y aporta nuevos datos sobre el primitivo retablo, Caso Fernández, Francisco de, «Historia del retablo mayor», Liño, 10, Oviedo, 1991, pp. 74-75 e ÍD., «Historia del retablo mayor de la catedral de Oviedo», Academia, núm. 74, Madrid, 1992, pp. 419-422.

9 Cuesta, Guía de la catedral, pp. 78 y 76, respectivamente (reed. 1995, pp. 57 y 55, resp.).

10 A.C.O.: cabildo del lunes, 26 de noviembre de 1487, Acuerdos capitularés de 1487 y 1488, fol. XXIVr, publicado por Caso Fernández, Francisco de, Colección documental sobre la catedral de Oviedo (1300-1520), vol. I, Gijón, Monumenta Histórica Asturiensia, 1982, doc. 69, pp. 55-56. ÍD., «Historia del retablo», 1992, pp. 420-421.

${ }^{11}$ A título comparativo, en 1449, el cabildo ovetense contrató a Nicolás de Bruselas para la maestría de obras de la catedral por 35 maravedises de jornal (Caso, Colección documental, I, doc. 10, pp. 16-17).

${ }_{12}$ Risco, España Sagrada, t. XXXIX, p. 76b. La sillería gótica fue tallada por Alejo de Vahía y otros maestros extranjeros bajo su dirección (Ara Gil, Clementina Julia, «La intervención del escultor Alejo de Vahía en la sillería de coro de la catedral de Oviedo» [1991], en Anales de Historia del Arte. (Homenaje al profesor dr. $d$. José María de Azcárate y Rístori), 4, Madrid, Editorial Complutense, 1993-1994, pp. 341-352. Para las obras de la basílica, vid. Caso Fernández, Francisco de, La construcción de la catedral de Oviedo (1293-1587), Oviedo, Universidad de Oviedo, 1981. Asimismo, el Museo de la Iglesia muestra una dádiva de este eclesiástico: un magnífico cáliz gótico de plata sobredorada con esmaltes (cat. O 6). 
ábside ochavado hasta el arranque del triforio, hoy oculto), tuvo que ser desmontado para dejar sitio al que hoy existe, iniciándose entonces la dispersión del conjunto ${ }^{13}$. Esta pudo ser la causa de que algunas de sus pinturas (Parcerisa, en 1856, emplea el plural: un «retablo de costosas pinturas») fuesen a parar a Santa María del Naranco. Las cesiones y ventas de mobiliario viejo o en desuso fueron práctica habitual de las grandes comunidades y cabildos religiosos y, por tanto, no debería parecer forzada esta interpretación a la hora de proponer una explicación más verosímil a la procedencia de una obra semejante. Además, la iconografía, técnica pictórica e indumentaria de esta tabla son propias de la época de actuación en Oviedo de Pedro de Mayorga (1487). La Asunción de la Virgen volverá a aparecer en el nuevo retablo, esta vez en bulto y mostrando al promotor, el obispo don Valeriano Ordóñez de Villaquirán, vestido de pontifical, como donante. La secuencia ocupa el segundo piso del cuerpo de gloria y suele atribuirse al escultor flamenco Giralte de Bruselas (c. 1512-1517). Tampoco debería extrañar la sustitución del retablo un cuarto de siglo después de la intervención de Pedro de Mayorga. Recuérdese que los trabajos de 1487 encomendados a Mayorga debieron ser, con toda probabilidad, labores de reforma y ampliación de un viejo conjunto. Además, ejemplos de inversiones suntuarias seguidas en el tiempo no son infrecuentes, sobre todo, en medios tan voluntaristas como las catedrales, sujetas directamente al capricho del cabildo o de los prelados ${ }^{14}$.

La Asunción del Museo de la Iglesia de Oviedo es pieza de gran calidad y claramente asignable al estilo descrito para la producción del Maestro de Palanquinos. Activo en la diócesis de León, principalmente en la Tierra de Campos y riberas del Esla, durante el último cuarto del siglo XV y primeros años del XVI ${ }^{15}$, el Maestro de Palanquinos fue identificado (como es sabido) por don Manuel Gómez-Moreno en 1908 a partir de seis tablas procedentes de un retablo del templo parroquial de Nuestra Señora de la Asunción de Palanquinos (León), integradas desde 1903 en el nuevo retablo mayor de la catedral leonesa ${ }^{16}$. Su estilo, perfilado después por Chandler Rathfon Post ${ }^{17}$, acusa el influjo del procedimiento minucioso y realista de la escuela flamenca, con detalles de afectada estilización anatómica que recuerdan a Dierik Bouts $(\dagger 1475)$ y a otros maestros de la escuela de Lovaina del tercio central del siglo XV; pero también a pintores hispano-flamencos como Fernando Gallego (documentado entre 1466-1507) o su hermano Francisco. La suntuosidad decorativa mudéjar (presente en los ricos y variados fondos dorados con grabados de atauriques y lacería) y, en algunas obras,

13 Para el retablo hispano-flamenco del presbiterio catedralicio (1512-1531), labrado por Giralte de Bruselas y Juan de Balmaseda, y policromado por Miguel de Bingueles y León Picardo, vid. Gómez-Moreno Martínez, Manuel, «I.- El retablo mayor de la catedral de Oviedo», Archivo Español de Arte y Arqueología, 25, t. IX, Madrid, 1933, pp. 1-6; Cuesta Fernández, José (presb.) y Arribas, Filemón, «II.- La documentación del retablo, transcrita por», A.E.A.A., 25, t. IX, Madrid, 1933, pp. 7-20; Cuesta, Guía de la catedral, pp. 72-79 y 171-173 (reed. de 1995, pp. 50-58 y 279-282), y Caso, 1991 y 1992.

${ }_{14}$ En Asturias existe otro caso parecido. El retablo mayor de la colegiata de Santa María la Mayor de Salas, templo fundado por el arzobispo de Sevilla don Fernando de Valdés, contó con un primer retablo labrado por Juan Bautista Portigiani en 1568 que fue sustituido por otro del Taller de Toro en 1606, más acorde con la suntuosidad y dimensiones requeridas por el templo y los testamentarios (vid. González Santos, Javier, «El escultor florentino Juan Bautista Portigiani. Noticias de sus obras en Asturias», Boletín del Seminario de Estudios de Arte y Arqueología, t. LII, Valladolid, 1986, pp. 301-302 e ÍD., «El taller de Toro en Asturias (obras y documentos del escultor Juan Ducete Díez)», B.S.A.A., t. LV, Valladolid, 1989, pp. 411-430).

${ }_{15} \mathrm{La}$ actuación de este maestro parece que también se extendió hasta tierras extremeñas, coincidiendo con la de Fernando Gallego en Trujillo (Ramos Rubio, José Antonio, «La Crucifixión, una obra inédita del Maestro de Palanquinos», Archivo Español de Arte, 258, t. LXV, Madrid, 1992, pp. 228-231).

16 Gómez-Moreno Martínez, Manuel, Catálogo monumental de España. Provincia de León (1906-1908), Madrid, Ministerio de Instrucción Pública y Bellas Artes, 1925 (hay reed. facsimilar: León, 1979), vol. I, p. 278. 
los modelos icónicos, languidez expresiva y efectos espaciales de sus pinturas llevan el sello del artista palentino Pedro Berruguete (Paredes de Nava, c. 1455 - ¿Ávila? † antes del 6 de enero de 1504). Para la villa de Mayorga de Campos (Valladolid pero diócesis de León por entonces), probable localidad de nacimiento del pintor Pedro de Mayorga, pintó los retablos de Santa Marina (antigua colección Masaveu, hoy propiedad del Principado de Asturias) ${ }^{18}$ y el de Santa María de Arbás, de 1498 (ahora en el templo parroquial de El Salvador) ${ }^{19}$. También hay obras suyas en la localidad vallisoletana de Villalón de Campos (retablo mayor del templo parroquial de San Juan Bautista) ${ }^{20}$ y León (el Descendimiento, o, acaso su mejor trabajo, San Cosme y San Damián de la catedral, y la Caída de los ángeles rebeldes del Museo de León). Recientemente, se ha sugerido un nombre, aunque sin convencimiento, para la identificación de este esquivo maestro: el del pintor sahagunés Juan de Santa Cruz ${ }^{21}$.

Aparte de la técnica del óleo y del realismo figurativo flamenco, la tabla del Museo diocesano ovetense también revela una práctica de la iconografía mariana y del estilo de Pedro Berruguete muy precoces (confróntese ésta con su Coronación de la Virgen del Museo de Bellas Artes de Asturias) ${ }^{22}$, hasta el punto de que se podría llegar a suponer una relación profesional entre ambos maestros, más concretamente de Palanquinos como grabador en oro y estofador de ciertas obras tempranas de Berruguete, en concreto, de los Santos Cosme y Damián de Covarrubias o del retablo de San Juan Bautista de Santa María del Campo (c. 1483-1490). Berruguete, retornado a España en 1482/1483 después de una estancia en Italia y avecindado en su villa natal (localidad de la Tierra de Campos y zona de actuación del Maestro de Palanquinos), probablemente habría tenido que recurrir a especialistas en labores de grabado mudéjares para adaptar su estética quattrocentista a los gustos castellanos; en esta circunstancia es en la que podría hallarse el Maestro de Palanquinos.

Asimismo, rasgos característicos del estilo de Palanquinos se perciben en el modelo facial de la Virgen (un óvalo acusado con la frente muy despejada; nariz alargada remachada en unas alas de doble bucle, boca pequeña de labios finos y silueta de piñón, y mentón con hoyuelo). El aire de imperturbabilidad y el gesto ensimismado de las figuras de este maestro también están presentes en la Asunción de Oviedo, al igual que las manos delgadas, con dedos exageradamente largos y de frágil apariencia. Otros pormenores, como la semejanza de los motivos del rameado estofado sobre la túnica de Nuestra Señora con los de la santa Marina del retablo de Mayorga de Campos, parecen datos suficientes y no una mera coincidencia para asignar la tabla del Museo diocesano de Oviedo a la producción del Maestro de Palanquinos y, en lógica correspondencia, servir de término de referencia para datar el conjunto de Mayorga alrededor de 1487. La pervivencia de superficies doradas grabadas a buril y punzón para los brocados e indumentaria de la Virgen, nimbo y fondos (trazos de losanges

17 Post, Ch. R., A History of Spanish Painting, Cambridge (Mass.), Harvard University Press, 1933, vol. IV, 1. ${ }^{\mathrm{a}}$ pte., pp. 155-169.

${ }_{18}$ Pérez Sánchez, Alfonso Emilio y Barón, Javier, Colección Pedro Masaveu, cincuenta obras, Oviedo, Museo de Bellas Artes de Asturias, 1995, cats. $8 a, 8 b$ y $8 c$, pp. 28-31. El retablo constaba de, al menos, veintidós tablas, adquiridas por Pedro Masaveu Petterson en 1969.

19 Post, op. cit., vol. IV, 1. ํ. pte., pp. 168-170.

${ }^{20}$ Ibídem, pp. 162-163.

21 Nieto Soto, Pilar, «Nueva obra del llamado Maestro de Palanquinos y una propuesta de identificación», Archivo Español de Arte, 267, t. LXVII, Madrid, 1994, pp. 305-308.

${ }^{22}$ Proviene de la colección de don Pedro Masaveu Petterson (adquirida en 1984) y hoy es propiedad del Principado de Asturias. Silva Maroto, María del Pilar, ápud Pérez Sánchez, Alfonso Emilio (dir.), Obras maestras de la colección Masaveu, Oviedo, Museo de Bellas Artes de Asturias, 1988, cat. 9, pp. $42-45$ y, Pérez Sánchez y Barón, Colección Pedro Masaveu, cat. 7, pp. 26-28, con bibliografía crítica en ambos casos. 

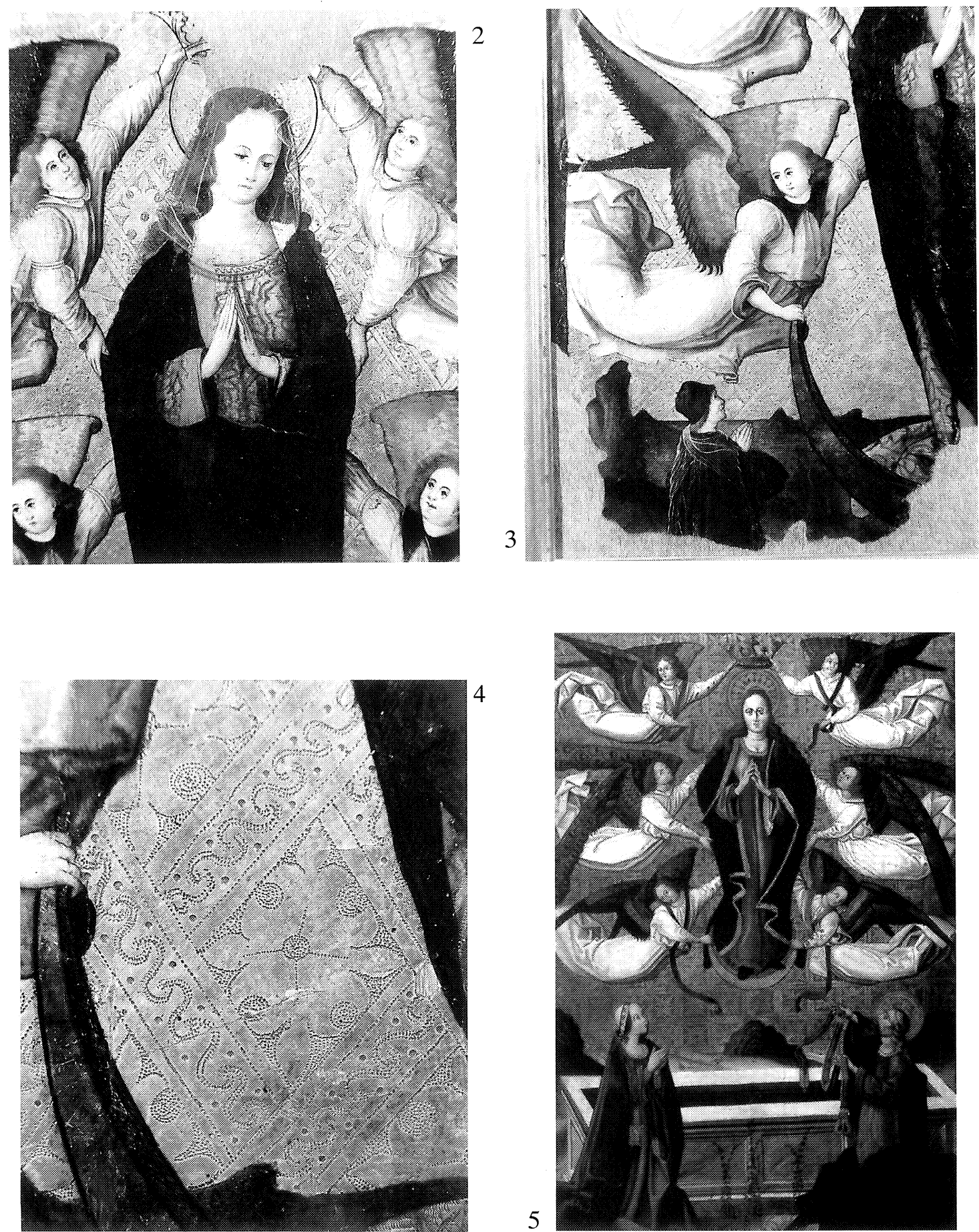

Figura 2. Asunción de Nuestra Señora, detalle de la figura 1 (Foto Alonso).

Figura 3. Ángel y donante, detalle de la figura 1 (Foto Alonso).

Figura 4. Detalle de los motivos grabados sobre el fondo dorado de la tabla (Foto Alonso).

Figura 5. Maestro de Palanquinos ¿Pedro de Mayorga?, Asunción de Nuestra Señora con santo Tomás y una donante, temple y óleo/tabla, 136 x $92 \mathrm{~cm}$., colección particular. 
cargados de florones, listas de grecas ondúlantes y líneas de punteados), el rotundo silueteado, el país de estilizada concepción y con escasa ambientación, y el tamaño jerárquico que diferencia las figuras celestiales del donante, son indicios de rémoras formativas o de exigencias de la clientela que vinculan esta pintura a los gustos y modas mudéjares y a la tradición hispana del estilo gótico-internacional (más concretamente, por vecindad geográfica, a la del maestre Nicolás Francés - documentado entre 1434 y $† 1468$-).

Muy parecida a esta del Museo de la Iglesia de Oviedo es la Asunción de Nuestra Señora con santo Tomás y una donante, recientemente «repatriada» y expuesta ${ }^{23}$. La tabla fue atribuida por Post en 1947 al Maestro de Palanquinos aunque con algunas reservas en cuanto a la calidad que sugieren la adscripción a su taller o círculo, opinión muy acertada a la vista de la mayor finura y corrección que, en cambio, sí tiene la tabla de Oviedo y otras obras indiscutibles de este maestro. Idéntico asunto pero sin donante aparece en el que fue retablo mayor de la parroquia de Santa María de Arbás de Mayorga de Campos, pintado en 1498 (segundo piso, calle del lado de la epístola inmediata al cuerpo de gloria).

Aceptada esta posibilidad y verificada la identidad estilística de la Asunción del Museo de la Iglesia de Oviedo con otras obras del Maestro de Palanquinos, de la documentación catedralicia ovetense se puede inferir también la verdadera identidad del ignoto pintor. La cronología, avecindamiento en la ciudad de León y el apellido gentilicio (Mayorga, población de la Tierra de Campos, donde pintó los retablos de Santa Marina y Santa María de Arbás) son otros tantos argumentos a favor del reconocimiento de Pedro de Mayorga con dicho Maestro o, en su caso, un oficial o discípulo, del autor de las pinturas hasta ahora etiquetadas con el toponomástico «Palanquinos».

De Pedro de Mayorga no conozco más noticias que las ya referidas a su trabajo en la basílica ovetense. Sí hay, en cambio, referencias documentales a un dorador, Juan de Mayorga el Mozo, que intervino como tal en el desaparecido retablo mayor del monasterio benedictino de San Salvador de Oña (Burgos). Los libramientos por su trabajo son de los años 1463-1465 ${ }^{24}$. Ignoro el grado de parentesco que pudiera haber existido entre Juan y Pedro de Mayorga, pero no sería descabellado pensar que fuesen hermanos, si atendemos al sobrenombre del dorador de Oña: el Mozo, hijo, por tanto, de otro Juan de Mayorga, el Viejo, verosímilmente también pintor y dorador. La profesión de ambos redunda aún más en presumir una vinculación familiar, que, teniendo presente la suntuosidad y variedad de motivos grabados en oro que muestran las tablas del Maestro de Palanquinos, invitan a apurar los argumentos de identificación entre éste y los Mayorga.

A finales de 1499, aparece documentado en las obras de la catedral de Toledo un ensamblador o tallista apellidado Mayorga, comprometido, junto a Diego Copín de Holanda, en la construcción, nada menos, del retablo mayor de la sede primada:

23 Pỏst, Spanish Painting, vol. IX, 2. pte., 1947, pp. 800-801, fig. 333. Pérez Sánchez, Alfonso Emilio, Pinturas recuperadas, Sevilla, Fundación Focus, 1996, cat. 13, p. 56 e ÍD., ídem, Oviedo, Museo de Bellas Artes de Asturias, 1997, cat. 6, pp. 38-39, con bibliografía crítica.

24 Silva Maroto, María del Pilar, Pintura hispanoflamenca castellana: Burgos y Palencia. Obras en tabla y sarga, Valladolid, Consejería de Cultura y Bienestar Social de la Junta de Castilla y León, 1990, vol. I, pp. 91, 128 y 177 y vol. III, documento núm. 31, pp. 987-988 (también ÍD., «Pintura hispanoflamenca en Burgos: el antiguo retablo mayor del monasterio de Oña», en Actas del XXIII Congreso Internacional de Historia del Arte, Granada, 1973, vol. I, pp. 489-495, con otros datos biográficos de Juan de Mayorga en Oña que llegan hasta el 29 de agosto de 1466). El retablo, desmantelado en 1756, fue labrado por el monje Pedro de Lorena y contenía tablas del pintor burgalés Juan Sánchez, el Mozo (c. 1463-1465). 
«En 28 de diciembre del dicho año, salieron Mayorga y Copín, imaginario, a ajustar en Ladrada el aliso necesario para la talla e imaginería del retablo» ${ }^{25}$.

La coincidencia del apellido y la cercanía de las fechas sugieren la posibilidad de que se tratara de la misma persona que trabajó en el retablo de Oviedo; pero lo limitado de la noticia recomienda la prudencia. No obstante, la nutrida presencia de artistas burgaleses en Toledo a principios del siglo XVI vendría a justificar la residencia de Mayorga, un artífice castellano-leonés, en Toledo, cuya catedral, por aquellos años, emprendía ambiciosas empresas decorativas en clave renacentista. Pedro Berruguete, Felipe Vigarny, Juan de Borgoña son figuras cuya actividad se localiza primero en Castilla la Vieja para, de inmediato, documentarse en Toledo con el cambio de siglo. Quizás la relación de Mayorga con Pedro Berruguete, ya apuntada, pudiera tener algo que ver con la presencia de aquél en Toledo en 1499.

JAVIER GONZÁLEZ SANTOS Universidad de Oviedo

\section{«NUEVOS DIBUJOS DE LA PLAZA MAYOR DE MADRID»}

Como mercado y centro ceremonial principal, la Plaza Mayor era el más importante proyecto de arquitectura civil en el Madrid de los Austrias. Con la forma de su arquitectura, la plaza estableció una norma de diseño para la reforma urbana de la naciente capital española. Los dibujos arquitectónicos de la Plaza Mayor de esta época son raros y, así, la reciente aparición de dos nuevas representaciones en el Archivo de Villa de Madrid merecen atención especial ${ }^{1}$.

El primero de los dibujos es un plano interior de gran rareza. Con fecha 24 de octubre de 1618, el dibujo ilustra la primera planta residencial encima de la Carnicería, al lado meridional de la plaza (Fig. 1). El dibujo nos da una clara idea de los espacios interiores en las plantas superiores de la Plaza Mayor ${ }^{2}$. En este caso, la residencia está compuesta de cinco aposentos, dos alcobas, dos cocinas, y tres salas con balcones que dan a la plaza.

25 Pérez Sedano, Francisco, Datos documentales inéditos para la Historia de Arte Español. Notas del Archivo de la Catedral de Toledo, redactadas sistemáticamente, en el siglo XVIII, por el canónigo-obrero Don-, Madrid, Centro de Estudios Históricos, 1914, p. 22. Mayorga no figura, en cambio, en la nómina de artífices que trabajaron el retablo publicada por Sixto Ramón Parro, (Toledo en la mano, Toledo, 1857, tomo I, pp. 93-94 y 91-101 pássim). La hechura de esta importante obra abarcó los años 1499-1504, coincidiendo con la prelatura del cardenal fray Francisco Jiménez de Cisneros.

Los dibujos protagonistas de este artículo son nuevos testamentos de la riqueza de la documentación conservada en el Archivo de Villa de Madrid (AVM). El autor desea expresar su sincera gratitud a José María Bernáldez, Director, y a Rosario Sánchez y Carmen Cayetano por su ayuda generosa durante años investigando en el archivo municipal. También agradezco a Claudia Sieber quien me ha dirigido al segundo de los dibujos analizados aquí, y a Consuelo García Devesa por su ayuda en la traducción del artículo. Para una historia revisada de los edificios, usos, y significaciones de la Plaza Mayor de Madrid en su contexto local, español, e internacional, véase la tesis doctoral del autor, The Plaza Mayor of Madrid: Architecture, Urbanism, and the Imperial Capital, 1560-1640, Princeton University, 1996.

- 2 AVM: Secretaría 1-163-3. Este dibujo, encontrado en 1995, nos hace vislumbrar la enorme riqueza de documentos que se encuentra en este archivo, y la imperiosa necesidad de prestar cuidadosa atención a este tesoro. Para una discusión sobre la importancia de viviendas de múltiples pisos en Madrid, véase Bonet Correa, Antonio, «El 